\title{
INDONESIA - A GOLDMINE OF DARK TOURISM DESTINATIONS
}

\section{Ioana Prodan}

Doctoral School of Economic Sciences, Faculty of Economic Sciences, University of Oradea, Romania ioana.prodan30@live.com

\begin{abstract}
Known for its significant potential in the tourism industry, Indonesia fails to promote dark tourism destinations as one of their main pillars of national tourism. As some countries were bold enough to create tourist attractions out of the catastrophes that hit them during their history, Indonesia holds one of the most death obsessed culture in the world, but it is not a strong dark tourism destination. The purpose of this paper is to analyze the potential of dark tourism destinations Indonesia has, the motivation of "dark tourists" consumers and the approach of Indonesians towards dark tourism.
\end{abstract}

Keywords: dark tourism, macabre tourism, zombie tourism

JEL classification: $Z 30$

\section{Introduction}

Dark tourism involves traveling to places that have encountered, or are associated with, death, disaster, depravity, misfortune, and the macabre as Lennon and Foley (1999) defined it. The "dark tourism" term was first pointed out by Foley and Lennon (1996b) as a "tourist interested in recent death, disaster and atrocity" borne of a "fundamental shift in a way in which death, disaster and atrocity are being handled by those who offer associated tourism products". However, they were not the first to refer to death related destinations. Rojek (1993) called this concept of visiting death related site as "black-spots", or "the commercial developments of grave sites and sites in which celebrities or large numbers of people have met with sudden and violent death".

The purpose of this paper is to analyze the potential of dark tourism destinations Indonesia has, the motivation of "dark tourists" consumers and the approach of Indonesians towards dark tourism.

\section{Dark tourism and travel motivation}

Dark tourism creates a unique yet controversial concept as it offers an uncommon feeling and atmosphere that are grief, sadness, and guilt in contrast to other kind of tourism sites (beaches, mountains, metropolitan, etc.) which presents joyful feelings to the tourist as Bittner (2011) states. Dark tourism in Indonesia might have a huge potential. The potentiality of dark tourism is not only accelerating recovery process in post disaster context, in which case community reinforces its resiliency to adversity, but by recycling obliterated cities into a more profitable spectacle has been widely studied by specialists from different angles (Seaton, 1996; Foley\&Lennon, 2000; Strage \& Kempa, 2003; Korstanje \& Ivanov, 2012). There might be an unwillingness to tolerate the intrusion of the new and based of that unwillingness, the host population might be against opening up some dark tourism sites. Indonesian government tends to focus on "white" tourism of Indonesia as beaches and metropolitan areas such as Jakarta, Bali or Batam. 


\subsection{Travel motivation}

People are more attracted to those beautiful and relaxing destinations than to dark tourism destinations. When traveling, people are trying to fulfill their needs. As Van Vuuren \& Slabbert (2012) mention, tourist motivation has been an important aspect to be researched in the tourism industry. It is used to predict the travel behaviour and destination choice. Motivation can be seen as an internal urge, as a process of leading people to behave the way they do.

Yuill (2003) tried to conceptualize the idea of Push and Pull factors of dark tourists' motivations:

Table 1: Push and Pull factors

\begin{tabular}{|c|c|c|}
\hline No. & Push Factor & Definition \\
\hline 1 & Heritage & site $\quad$ A special or individual possesion with the \\
\hline 2 & History & Experiential learning \\
\hline 3 & Guilt & $\begin{array}{l}\text { Intentions to honor or commemorate } \\
\text { victims }\end{array}$ \\
\hline 4 & Curiosity & $\begin{array}{c}\text { Embracing variant motives to fulfill } \\
\text { fascination for macabre and unique sites }\end{array}$ \\
\hline 5 & $\begin{array}{ll}\text { Death and } \\
\text { dying }\end{array}$ & $\begin{array}{l}\text { Intention to cope with a personal question } \\
\text { regarding death, dying and tragedy }\end{array}$ \\
\hline 6 & Nostalgia & $\begin{array}{l}\text { To undergo a regretful, nostalgic or } \\
\text { wistful mood from the past }\end{array}$ \\
\hline \multicolumn{2}{|r|}{ Pull factor } & Definition \\
\hline 1 & Education & $\begin{array}{l}\text { Interested in understanding the history } \\
\text { behind }\end{array}$ \\
\hline 2 & Remembrance & $\begin{array}{l}\text { To direct or take an interest in respectful } \\
\text { action, to venerate the past so people and society } \\
\text { can prevent past mistakes }\end{array}$ \\
\hline 3 & Artifacts & To see the evidence of culture or history \\
\hline 4 & $\begin{array}{r}\text { Sight } \\
\text { sacralization }\end{array}$ & The process of assigning cultural identity \\
\hline
\end{tabular}

Source: Bigley et al (2010)

According to Isaac and Cakmak (2013) self-understanding, curiosity, exclusiveness and conscience are also motivations to visit dark tourism sites. Self-understanding is a motive to see more insights of a certain site and to feel the symphathy towards the victim, whereas curiosity is exactly the opposite, you're curious to see the place and to answer to the questions "why?", "how?".

\section{Dark tourism destinations in Indonesia}

South Sulawesi is a province of Indonesia, and it is located in the Sulawesi Island. This region is inhibited by Torajan people. Most of them are Christians, due to the Dutch missionaries in the early 1900s, but there are Muslims as well and the animist religion, a religion of those people, also called "the way". The tourists that are eager to have a firsthand fun and fright touristic encounter with the "undead" are taking part in many festivals that are held in some indigenous communities along Indonesia. 


\subsection{Ma Nene festival}

As stated before, the Indonesian culture is a death oriented one. One of the main attractions of dark tourism sites is the Ma Nene festival which is held every year in August, and it is a ritual that consists in cleaning the corpses which is held in Tana Toraja, During this ritual the dead are exhumated to be groomed, washed and to get a new change of clothes. After the grooming ritual is finished, the new dressed bodies of the deceased are walked around the village while new coffins are prepared for them to return to their graves.

Stating from this ritual and together with tourist fascination with the cadavers and a zombie manie of the people, a new term has been born for dark tourism, which is zombie tourism. Although mummies can be found in Egypt as well, this term of zombie tourism is located in Indonesia due to this Ma Nene festival, where the relatives of the dead "walks" him/her around year after it's funeral.

\subsection{The Torajan burial methods}

The Torajans have multiple way of celebrating the death of a person. After the actual death, the body is wrapped and covered in many layers and kept by the family at home. Sometimes the period between the death and the funeral can extend to several years, until the family is able to gather enough money to organize an extravagant funeral ceremony. During the waiting period between the death and the burial, the ceremony asks for buffaloes and pigs to be slaughter.

One of the burial methods used in Tana Toraja is the stone-carved cliff graves. The family dig a cave inside a rocky cliff and the corps is places in a gravestone.

A second method used for burial is hanging carved graves. The corps is left exposed and hanging on a cliff in a wooden casket. The result of this method is that eventually the casket will fall and the body inside the casket will become just bones that will scattered over the ground.

Another method is dedicated for the children, and it is called baby tree graves. The tree is seen as a symbol of life in their culture and the babies and children are too young to have such a complicated and long funeral ceremony as those two described above. So, for the children and infants, they pick a hollow tree that symbolize "the new mother" of the dead child and the corpse is put inside the tree.

\subsection{Other dark tourism destinations}

Not all dark tourism destinations in Indonesia are funeral related and in the middle of the jungle, some of them are in the metropolitan area and are warfare destinations such as exVietnam's refugee camp in Batam, Lubang Buaya in Jakarta, Mandor killing fields in West Kalimantan, Trunyan Basket Burial site in Bali or Lawang Sewu in Semarang.

\section{Conclusions}

Indonesia has a rich and unique heritage and history, which gives many destinations of almost any kind of tourism. Their death-oriented culture holds a strong word in Indonesia being a dark tourism destination. Although the Western civilization is more orientated to dark tourism sites, the Asian population will become, in time, attracted to this tourism niche.

Even though the main purpose of visiting Indonesia might not be dark tourism for more than half of their tourists, they became dark tourism consumers thanks to many day trips organized by the local travel agencies. As it might be easy to travel to some famous site, it might be hard to get all the information from the locals, especially the ones that are living in the jungle and are not touch by the globalization and increasing tourism activity. 


\section{References}

Bigley, J. D., Lee, C. K., Chon, J., \& Yoon, Y. (2010). Motivations for war-related tourism: A case of DMZ visitors in Korea. Tourism Geographies, 12(3), 371-394.

Bittner, M. (2011). 'Dark tourism': Evaluation of visitors experience after visiting thanatological tourist attractions. Turizam, 15(4), 148-158.

Foley, M. and Lennon, J. (1996a) JFK and dark tourism: a fascination with assassination. International Journal of Heritage Studies 2(4), 198-211.

Foley, M. and Lennon, J. (1996b) Editorial: Heart of darkness. International Journal of Heritage Studies 2(4), 195-197.

Foley, M., \& Lennon, J. J. (2000). Dark tourism. Continuum.

Henderson, J. C. (2009). The meanings, marketing, and management of heritage tourism in Southeast Asia. Cultural heritage and tourism in the developing world: a regional perspective, 73-92.

Hartmann, R. (2014). Dark tourism, thanatourism, and dissonance in heritage tourism management: New directions in contemporary tourism research. Journal of Heritage Tourism, 9(2), 166-182.

Isaac, R. K., \& Çakmak, E. (2014). Understanding visitor's motivation at sites of death and disaster: the case of former transit camp Westerbork, the Netherlands. Current Issues in Tourism, 17(2), 164179.

Korstanje, M. E., \& Ivanov, S. H. (2012). Tourism as a form of new psychological resilience: The inception of dark tourism. CULTUr-revista de Cultura e Turismo, 6(4), 56-71.

Lennon, J. J., \& Foley, M. (1999). Interpretation of the unimaginable: The US Holocaust Memorial Museum, Washington, DC, and "dark tourism". Journal of Travel Research, 38(1), 46-50.

Light, D. (2017). Progress in dark tourism and thanatourism research: An uneasy relationship with heritage tourism. Tourism Management, 61, 275-301.

Rojek, C. (1993). Ways of escape: Modern transformations in leisure and travel. Springer.

Seaton, A. V. (1996). Guided by the dark: From thanatopsis to thanatourism. International Journal of Heritage Studies, 2(4), 234-244.

Strange, C., \& Kempa, M. (2003). Shades of dark tourism: Alcatraz and Robben Island. Annals of tourism research, 30(2), 386-405.

Van Vuuren, C., \& Slabbert, E. (2012). Travel motivations and behaviour of tourists to a South African resort. Tourism \& Management Studies, 295-304.

Yuill, S. M. (2004). Dark tourism: understanding visitor motivation at sites of death and disaster (Doctoral dissertation, Texas A\&M University). 